\title{
Hepatitis B and C, HIV, Syphilis Seroprevalences and Asymptomatic Carriage of Hemoparasites Among Blood Donors at the Douala General Hospital in Cameroon, Central Africa
}

\author{
Cyrille ND0 ${ }^{1,2 *}$, Jaccotting Thierry Ewane Ngalle $^{1}$, Symphorien Ewodo ${ }^{3}$, Clemence Olemba ${ }^{3}$, \\ Dieudonné Adiogo ${ }^{1}$ \\ ${ }^{1}$ Department of Biological Sciences, Faculty of Medicine and Pharmaceutical Sciences, Cameroon
}

${ }^{2}$ Malaria Research Laboratory, Organization of Coordination for the fight against Endemics in Central Africa (OCEAC), Cameroun

${ }^{3}$ Douala General Hospital, Hematology Laboratory, Cameroon

*Corresponding author: Cyrille NDO, Department of Biological Sciences, Faculty of Medicine and Pharmaceutical Sciences,

Douala, Cameroon

\section{ARTICLE INFO}

Received: 幽 June 12, 2019

Published: 业 June 19, 2019

Citation: Cyrille NDO, Jaccotting Thierry E N, Symphorien E, Clemence O, Dieudonné A. Hepatitis B and C, HIV, Syphilis Seroprevalences and Asymptomatic Carriage of Hemoparasites Among Blood Donors at the Douala General Hospital in Cameroon, Central Africa. Biomed J Sci \& Tech Res 18(5)-2019. BJSTR. MS.ID.003227.

Keywords: Blood Donors; HIV; Hepatitis B And C; Syphilis; Hemoparasites; General Hospital of Douala

Abbreviations: P: Plasmodium, HIV: Human Immunodeficiency Virus, HCV: Hepatitis C Virus, HBV: Hepatitis B Virus, WHO: World Health Organization, HTLV: Human $\mathrm{T}$ Cell Leukemia/Lymphoma Virus, ECLIA: Electrochemiluminescence Immunoassay, CPDA-1: Citrate Phosphate Dextrose Adenine, EDTA: Ethylene Diamine Tetra-Acetic Acid, L: Loa, ECCAS: Economic Community Of Central African States, AIDS: Acquired Immune Deficiency Syndrom, RDT: Rapid Diagnostic Tests
ABSTRACT

Background: Blood transfusion is a life-saving intervention, but that can also promote transmission of various infectious and parasitic diseases. To assure safe blood transfusion, all donor are systematically screened for transfusion-transmissible infections including HIV, hepatitis (B and C) and syphilis. However, less attention is paid for other endemic curable infections caused by hemoparasites such as malaria, and that may represent a threat for the safety of blood transfusion. This study aimed to assess the prevalence of transfusion-transmittable infections and hemoparasites in blood donors at the general hospital of Douala, with more emphasis on Plasmodium the causative agent of malaria.

Methodology: Donated blood were first screened for HIV, Hepatitis (B \& C) and syphilis infections. After exclusion of HIV, Hepatitis and syphilis infected bloods, the remaining ones were examined for the presence of hemoparasites including Plasmodium and microfilariasis species under light microscopy, after staining thick blood smears with Giemsa solution.

Results: A total of 410 people were received at the Douala General Hospital and 37 (9.02\%) were excluded based on exclusion criteria. Of the 373 pre-qualified donors, 41 (10.99\%) were found infected by at least one viral or syphilis infections, and their blood was disqualified for transfusion. The seroprevalence of HIV, HVB, HVC and syphilis was $3.48 \%, 4.83 \%, 1.88 \%$ and $1.07 \%$ respectively. Only two hemoparasite species namely Loa loa and P. falciparum were found, but the prevalence of asymptomatic malaria $(11.78 \%)$ was by far higher than that of microfilariasis $(0.60 \%)$. However, malaria parasitemia was in most of cases low, with estimated densities ranging between 1 and 50 trophozoïtes/ $\mu$ l.

Conclusion: We concluded that HIV and HBV are the greatest threats to blood safety in Douala, while underlining the necessity to test potential donors using rapid tests in order to avoid collection, manipulation and destruction of infected blood. The study also revealed moderate but non-negligible prevalence of asymptomatic P. falciparum infection in qualified blood samples, highlighting serious risk of transmission of this hemoparasite to receivers. We therefore re-advocate that all blood samples be additionally screened for malaria before transfusion in Cameroon where malaria is endemic in most parts of the country. 


\section{Background}

Blood transfusion consists in administering full blood or one of its components, that originates from an individual called donor, to one or many other individuals called receivers. This technique helps in saving millions of lives worldwide every year $[1,2]$. In developing countries, the demand for blood transfusion services is high due to endemicity of infections causing anemia, malnutrition, and surgical and obstetrical emergencies associated with blood loss [3,4]. Meanwhile blood transfusion remains an issue of major concern because of the scarcity of well secured blood, since blood transmitted infectious diseases are spread within the populations [5,6]. Human immunodeficiency virus (HIV), Hepatitis B (HBV), Hepatitis C (HCV) and syphilis are among the utmost threats to blood safety transfusion recipients and World Health Organization (WHO) therefore recommends that screening of all blood donations should be mandatory for these infections $[4,6]$. In addition, screening of donated blood for other infections, such as those causing malaria, Erythrovirus B19 or human T cell leukemia/ lymphoma Virus (HTLV), should be based on local epidemiological evidence [7].

In Sub-saharan African countries, malaria is of greatest concern among parasitic diseases known or suspected to be transmitted by blood transfusion [8]. Transfusion-transmitted malaria can have serious consequences, as infection with Plasmodium falciparum may prove rapidly fatal especially in non or less-immune recipients such as children under five years and pregnant women. A review of 17 studies carried out between 1980 and 2009 in sub-saharan countries where malaria is endemic revealed a median prevalence of $10.2 \%$ in blood donors $[9,10]$. This prevalence reached $55 \%$ in Nigeria, highlighting the necessity to care about transfusiontransmitted malaria, especially in endemic settings and when receivers present particular risk associated with young age, pregnancy or immunodepression. In Cameroon, malaria is endemic and remains a major public health problem. Malaria-related morbidity and hospital mortality where respectively $30.1 \%$ and $22.9 \%$ in 2014 [11]. Sadly, despite this high endemicity, blood is still not systematically screened for malaria prior transfusion. Consequently, data on potential risk of induced malaria by blood transfusion are essentially lacking, and this risk need to be addressed in order to improve safety of blood transfusion. The present study aimed to determine prevalence of viral, bacterial and hemoparasites infections and associated risk with blood transfusion among blood donors at the General Hospital of Douala, the biggest and more populated city of Cameroon, with more emphasis on Plasmodium the causative agent of malaria.

\section{Methods}

\section{Recruitment of Blood Donors}

A cross-sectional survey was carried out from December 2015 to May 2016 at the Blood Donors Reference Center of the General Hospital of Douala, situated about $10 \mathrm{~km}$ from the city center of
Douala, the largest city and economic capital of Cameroon. Blood donors were recruited among people of both sexes, all ethnic groups and all social strata, as volunteers or family donors. In general, they were 18 to 60 years old, above $50 \mathrm{~kg}$, showing no clinical signs of fever or evolutive sickness. Additionally, donors of female sex were non-pregnant, non-breastfeeding and non-menstruating. All potential blood donors were informed about the nature and the objectives of the study, and personal and demograpic data were recorded including the name, age, place of residence, phone number, type of blood donation (voluntary or family), marital status, level of study and profession. They were subsequently interviewed about their recent health history on malaria and the use of LLINs, and those that have had a recent contact with antimalarial drugs were removed from the study. All prequalified donors were offered pretest counseling after that they have been asked to sign an informed consent.

\section{Serological Tests and Hemoparasite Diagnosis}

Blood was collected between 8:30 am and 1pm. For each qualified donor, $450 \mathrm{ml}$ of blood were collected by venipuncture in a bag containing Citrate Phosphate Dextrose Adenine (CPDA-1) anticoagulant. Besides, another $5 \mathrm{ml}$ of blood were collected and were dispensed into ethylene diamine tetra-acetic acid (EDTA) tube, to serve for identification of $\mathrm{ABO}$ and rhesus blood groups. HIV, hepatitis (B \& C) were screened by electrochemiluminescence immunoassay (ECLIA) using automated Cobase411 analyzer (Roche Diagnostics, Indianapolis, IN, USA), while syphilis infection was diagnosed using Treponema pallidum Haemagglutination test. For identification of mobile microfilaria, a drop of fresh blood was placed on a slide and mixed with a drop of physiological saline, and the preparation was then covered with a cover slide and examined microscopically. In the other hand, blood samples from each donor enrolled in the study were screened by direct microscopic $(100 \times)$ visualization of Plasmodium parasites on thick blood smears stained with $10 \%$ Giemsa. Trophozoite density in blood was determined using semi quantitative count method following a semi-quantitative scale.

\section{Data Analysis}

Data were entered in Microsoft excel software (Microsoft Office 2013), then analyzed with SPSS 16 software (SPSS Inc., Chicago IL, USA) and Statview 5.0 (SAS Institute, Inc., USA). Data of prevalence (number of positive tests / total number of tests) were presented in percentages. The Odds Ratio of infections was determined using a logistic regression. The Fischer test was used to compare the averages. Statistical significance of all tests was set at $\mathrm{P}<0.05$.

\section{Results}

\section{Seroprevalence of HIV, HBC, HCV, Syphilis and Qualification of Blood Donors}

Overall, 410 people were received at the Douala General Hospital and $37(9.02 \%)$ were not included in the study on the 
basis of exclusion criteria mentioned above. Blood of the 373 pre-qualified donors was then screened for blood-transmitted infections including HIV, hepatitis $B$, hepatitis $C$ and syphilis. Of the 373 donors, 42 (11.26\%) were positive for one or two serological tests and their blood was not qualified for transfusion. The overall seroprevalence of HIV, HBV, HCV and syphilis were respectively $3.48 \%, 4.83 \%, 1.88 \%$ and $1.07 \%$. Two cases of co-infections

Table 1: Socio-demographic characteristics of pre-qualified blood donors and HIV and Syphilis seroprevalences at General Hospital of Douala.

\begin{tabular}{|c|c|c|c|c|c|c|}
\hline Characteristics & $\begin{array}{l}\text { HIV Positive/ } \\
\text { Tested (\%) }\end{array}$ & $\begin{array}{c}\text { Odds Ratio (95\% } \\
\text { CI) }\end{array}$ & P-Values & $\begin{array}{c}\text { Syphilis Positive/ } \\
\text { Tested (\%) }\end{array}$ & $\begin{array}{l}\text { Odds Ratio } \\
\text { (95\%CI) }\end{array}$ & P-Values \\
\hline \multicolumn{7}{|l|}{ Sex } \\
\hline Female & $2 / 32(6.25)$ & 1 & & $0 / 31(0.00)$ & 1 & \\
\hline Male & $11 / 341(3.23)$ & $0.49(0.09-2.41)$ & 0.3775 & $5 / 341(1.47)$ & $2.95 \times 105$ (NA) & 0.9881 \\
\hline \multicolumn{7}{|l|}{ Age (years) } \\
\hline$[18$ - 27] & $5 / 183(2.73)$ & 1 & & $3 / 183(1.64)$ & 1 & \\
\hline$[28-37]$ & $6 / 138(4.35)$ & $1.42(0.39-5.20)$ & 0.5926 & $0 / 138(0.00)$ & $1.21 \times 10-6(\mathrm{NA})$ & 0.9745 \\
\hline$[38-47]$ & $2 / 45(4.44)$ & $1.35(0.21-8.71)$ & 0.7517 & $2 / 44(4.55)$ & $1.27(0.09-18.67)$ & 0.86 \\
\hline$\geq 48$ & $0 / 7(0.00)$ & $6.547 \times 10-6(\mathrm{NA})$ & 0.987 & $0 / 7(0.00)$ & $4.36 \times 10-7(\mathrm{NA})$ & 0.9941 \\
\hline \multicolumn{7}{|l|}{ Marital statut } \\
\hline Single & $10 / 299(3.34)$ & 1 & & $3 / 296(1.01)$ & 1 & \\
\hline Married & $3 / 72(4.17)$ & $1.22(0.72-5.44)$ & 0.7972 & $2 / 72(2.78)$ & $4.97(0.31-77.27)$ & 0.2524 \\
\hline \multicolumn{7}{|l|}{ Study level } \\
\hline Primary & $1 / 25(4.00)$ & 1 & & $1 / 25(4.00)$ & 1 & \\
\hline Secondary & $9 / 231(3.90)$ & $2.19 \times 105(\mathrm{NA})$ & 0.9913 & $2 / 231(0.87)$ & $5.44 \times 104(\mathrm{NA})$ & 0.9965 \\
\hline University & $3 / 112(2.68)$ & $2.03 \times 105(\mathrm{NA})$ & 0.9914 & $2 / 112(1.79)$ & $1.74 \times 105(\mathrm{NA})$ & 0.9962 \\
\hline \multicolumn{7}{|l|}{ Type of donation } \\
\hline Voluntary & $1 / 13(7.69)$ & 1 & & $0 / 13(0.00)$ & 1 & \\
\hline Family & $12 / 359(3.34)$ & $0.33(0.03-3.18)$ & 0.3367 & $5 / 359(1.39)$ & $4.62 \times 105(\mathrm{NA})$ & 0.9919 \\
\hline \multicolumn{7}{|l|}{ Blood group } \\
\hline A & $3 / 102(2.94)$ & 1 & & $2 / 102(1.96)$ & 1 & \\
\hline $\mathrm{AB}$ & $1 / 11(9.09)$ & $3.19(0.28-36.43)$ & 0.3513 & $0 / 11(0.00)$ & $3.32 \times 10-6(\mathrm{NA})$ & 0.9896 \\
\hline $\mathrm{B}$ & $4 / 74(5.41)$ & $1.73(0.36-8.18)$ & 0.4916 & $1 / 74(1.35)$ & $0.68(0.05-8.43)$ & 0.7623 \\
\hline 0 & $5 / 185(2.70)$ & $0.78(0.18-3.42)$ & 0.7427 & $2 / 185(1.08)$ & $0.59(0.08-4.58)$ & 0.6111 \\
\hline \multicolumn{7}{|l|}{ Rhesus } \\
\hline Negative & $0 / 18(0)$ & 1 & & $0 / 18(0.00)$ & 1 & \\
\hline Positive & $13 / 354$ (3.67) & $1.74 \times 105(\mathrm{NA})$ & 0.9787 & $5 / 354(1.41)$ & $1.80 \times 105$ (NA) & 0.9913 \\
\hline
\end{tabular}

Table 2: Socio-demographic characteristics of pre-qualified blood donors and hepatitis B and C seroprevalences at General Hospital of Douala.

\begin{tabular}{|c|c|c|c|c|c|c|}
\hline Characteristics & $\begin{array}{l}\text { HBV Positive/ } \\
\text { Tested (\%) }\end{array}$ & $\begin{array}{l}\text { Odds Ratio } \\
\text { (95\%CI) }\end{array}$ & P-Values & $\begin{array}{c}\text { HCV Positive/ } \\
\text { Tested (\%) }\end{array}$ & $\begin{array}{l}\text { Odds Ratio } \\
\text { (95\%CI) }\end{array}$ & P-Values \\
\hline \multicolumn{7}{|l|}{ Sex } \\
\hline Female & $2 / 32(6.25)$ & 1 & & $2 / 31(6.45)$ & 1 & \\
\hline Male & $17 / 341$ (4.99) & $1.56(0.19-12.66)$ & 0.6787 & $6 / 341(1.76)$ & $0.99(0.32-1.25)$ & 0.084 \\
\hline \multicolumn{7}{|l|}{ Age (years) } \\
\hline$[18-27]$ & $7 / 183(3.83)$ & 1 & & $5 / 183(2.73)$ & 1 & \\
\hline$[28-37]$ & $8 / 138(5.80)$ & $1.95(0.65-5.91)$ & 0.2355 & $3 / 138(2.17)$ & $0.52(0.09-2.76)$ & 0.4421 \\
\hline$[38-47]$ & $3 / 44(6.82)$ & $1.87(0.40-8.65)$ & 0.4231 & $0 / 44(0.00)$ & $3.31 \times 10-6(\mathrm{NA})$ & 0.9784 \\
\hline$\geq 48$ & $0 / 7(0.00)$ & $6.51 \times 10-6(\mathrm{NA})$ & 0.9918 & $0 / 7(0.00)$ & $6.51 \times 10-6(\mathrm{NA})$ & 0.9911 \\
\hline
\end{tabular}




\begin{tabular}{|c|c|c|c|c|c|c|}
\hline \multicolumn{7}{|l|}{ Marital statut } \\
\hline Single & $15 / 299(4.17)$ & 1 & & $7 / 299$ (2.34) & 1 & \\
\hline Married & $3 / 72(4.17)$ & $0.69(0.17-2.84)$ & 0.6094 & 1/72 (1.39) & $0.99(0.09-9.81)$ & 0.9901 \\
\hline \multicolumn{7}{|l|}{ Level of study } \\
\hline Primary & $1 / 25(4.00)$ & 1 & & $3 / 25(12.00)$ & 1 & \\
\hline Secondary & $16 / 231(6.93)$ & $7.36 \times 105(\mathrm{NA})$ & 0.9943 & $4 / 231(1.73)$ & $7.87 \times 104(\mathrm{NA})$ & 0.9952 \\
\hline University & $1 / 112(0.89)$ & $9.61 \times 104(\mathrm{NA})$ & 0.9952 & $1 / 112(0.89)$ & $3.96 \times 104$ (NA) & 0.9898 \\
\hline \multicolumn{7}{|l|}{ Type of donation } \\
\hline Vuluntary & $0 / 13(0.00)$ & 1 & & $0 / 13(0.00)$ & 1 & \\
\hline Family & $18 / 359(5.01)$ & $3.47 \times 105(\mathrm{NA})$ & 0.9878 & $8 / 359(2.23)$ & $1.14 \times 105$ (NA) & 0.9898 \\
\hline \multicolumn{7}{|l|}{ Blood groups } \\
\hline A & $4 / 102(3.92)$ & 1 & & $2 / 102(1.96)$ & 1 & \\
\hline $\mathrm{AB}$ & $1 / 11(9.09)$ & $2.24(0.21-23.44)$ & 0.5006 & $0 / 11(0.00)$ & $6.24 \times 10-6(\mathrm{NA})$ & 0.9896 \\
\hline B & $4 / 74(5.41)$ & $1.29(0.30$ - 5.55) & 0.7341 & $2 / 74(2.70)$ & $1.54(0.19-12.40)$ & 0.6846 \\
\hline 0 & $9 / 185(4.86)$ & $1.23(0.36-4.18)$ & 0.7415 & $4 / 185(2.16)$ & $0.90(0.15-5.43)$ & 0.9095 \\
\hline \multicolumn{7}{|l|}{ Rhesus } \\
\hline Negative & $0 / 18(0)$ & 1 & & $1 / 18(5.56)$ & 1 & \\
\hline Positive & $18 / 354(5.08)$ & $6.18 \times 105(\mathrm{NA})$ & 0.9865 & $7 / 354(1.98)$ & $0.22(0.02-2.22)$ & 0.1993 \\
\hline
\end{tabular}

\section{Characteristic of Qualified Blood Donors}

After serological tests 331 blood donors (samples) were qualified for transfusion. The mean age of qualified donors was $28.98 \pm 7.27$ years (range 18-48 years) with predominance of donors belonging to age groups 18-27 (49.55\%) and 28-37 (36.86\%). Of these blood donors, majority were men (91.54\%) and most of them were single (80.36\%) Table 3. Three main professional groups were more represented including students (30.81\%), workers from private sector (30.21\%) and civil servants (25.99\%). There was also a predominance of family donors (96.37\%) and individuals of Rhesus positive (94.86\%). All blood groups of the ABO system were represented, with a predominance of the 0 group (49.85\%), followed by A (28.09\%), B (19.34\%) and AB (2.72\%) groups. Finally, $70.09 \%$ of blood donors have declared to use Long Lasting Insecticide Treated Nets (LLINs) as mean to prevent malaria Table 3.

Table 3: Socio-demographic characteristics of qualified blood donors at General Hospital of Douala.

\begin{tabular}{|c|c|c|c|}
\hline Characteristics & Categories & Number & Percentage (\%) \\
\hline \multirow[t]{2}{*}{ Sex } & Female & 28 & 8.46 \\
\hline & Male & 303 & 91.54 \\
\hline \multirow[t]{4}{*}{ Age range (years) } & [18 - 27] & 164 & 49.55 \\
\hline & [28 - 37] & 122 & 36.86 \\
\hline & {$[38-47]$} & 38 & 11.48 \\
\hline & $\geq 48$ & 7 & 2.11 \\
\hline \multirow[t]{7}{*}{ Profession } & Private workers & 100 & 30.21 \\
\hline & Civil servant & 86 & 25.99 \\
\hline & Scholar & 54 & 16.31 \\
\hline & Student & 48 & 14.5 \\
\hline & Informal sector & 28 & 8.46 \\
\hline & Housewife & 7 & 2.11 \\
\hline & Jobless & 8 & 2.42 \\
\hline \multirow[t]{3}{*}{ Marital status } & Single & 266 & 80.36 \\
\hline & Married & 65 & 19.64 \\
\hline & None & 3 & 0.91 \\
\hline \multirow[t]{3}{*}{ Study level } & Primary & 20 & 6.04 \\
\hline & Secondary & 202 & 61.03 \\
\hline & University & 106 & 32.02 \\
\hline \multirow[t]{2}{*}{ LLINs } & No & 99 & 29.91 \\
\hline & Yes & 232 & 70.09 \\
\hline
\end{tabular}




\begin{tabular}{|c|c|c|c|}
\hline Type of donation & Volunteer & 12 & 3.63 \\
\hline & Family & 319 & 96.37 \\
\hline \multirow[t]{4}{*}{ Blood group } & $A$ & 93 & 28.09 \\
\hline & $\mathrm{AB}$ & 9 & 2.72 \\
\hline & B & 64 & 19.34 \\
\hline & 0 & 165 & 49.85 \\
\hline \multirow[t]{2}{*}{ Rhesus } & Negative & 17 & 5.14 \\
\hline & Positive & 314 & 94.86 \\
\hline
\end{tabular}

\section{Hemoparasite Carriage}

Two hemoparasites species were identified including $\mathrm{P}$. falciparum the causative agent of malaria, and Loa loa which cause filariasis. However, the prevalence of asymptomatic malaria infection was higher (11.78\%) than those of filariasis $(0.60 \%)$. Plasmodium falciparum trophozoite density in blood was low and was estimated to vary between 1 to 50 trophozoites/ $\mu$ l.The factor that was associated with infection by P. falciparum was the nonuse of LLINs. The other factors such as age, marital status, level of study, type of donor, blood group, and Rhesus factor were not of great influence on the asymptomatic carriage of P. falciparum Table 4. The low number of microfilaria cases didn't allow us to perform multiparametric analysis, in order to identify risk factors associated with L. loa infection.

Table 4: Plasmodium falciparum prevalence among qualified blood donors at the General Hospital of Douala.

\begin{tabular}{|c|c|c|c|c|c|}
\hline Characteristics & Categories & $\begin{array}{c}\text { Positive To Pf } \\
\text { (Infection Rate) }\end{array}$ & Odds Ratio (OR) & IC95\% & P-Value \\
\hline \multirow[t]{2}{*}{ Sex } & Female & $2(7.14 \%)$ & 1 & & \\
\hline & Male & $37(12.17 \%)$ & 1.801 & $0.411-7.905$ & 0.4653 \\
\hline \multirow[t]{4}{*}{ Age } & [18 - 27] & 15(13.35\%) & 1 & & \\
\hline & [28 - 37] & $\begin{array}{c}17(13.93 \%)(13.93 \%) \\
(13.93 \%)\end{array}$ & 1.619 & $0.774-3.386$ & 0.2005 \\
\hline & [38 - 47] & 7 (18.42\%) & 2.258 & $0.850-5.999$ & 0.1022 \\
\hline & $\geq 48$ & $0(0 \%)$ & - & - & - \\
\hline \multirow[t]{2}{*}{ Marital statut } & Single & $31(11.61 \%)$ & 1 & & \\
\hline & Married & 7 (11.11\%) & 0.952 & $0.398-2.272$ & 0.9111 \\
\hline \multirow[t]{3}{*}{ Level of study } & Primary & $2(10 \%)$ & 1 & & \\
\hline & Secondary & 24 (11.88\%) & 0.93 & $0.26-3.324$ & 0.9112 \\
\hline & University & $12(11.32 \%)$ & 0.953 & $0.25-3.632$ & 0.9442 \\
\hline \multirow[t]{2}{*}{ Type of donor } & Volunteers & $1(8.33 \%)$ & 1 & & \\
\hline & Family & $38(11.88 \%)$ & 1.482 & $0.186-11.807$ & 0.7101 \\
\hline \multirow[t]{4}{*}{ Blood groups } & A & $12(12.77 \%)$ & 1 & & \\
\hline & $\mathrm{AB}$ & $1(11.11 \%)$ & 0.854 & $0.098-7.448$ & 0.8865 \\
\hline & B & $5(7.81 \%)$ & 0.579 & $0.194-1.732$ & 0.3284 \\
\hline & 0 & $2(12.73 \%)$ & 0.997 & $0.466-2.130$ & 0.9928 \\
\hline \multirow[t]{2}{*}{ Rhesus } & Negative & $1(5.88 \%)$ & 1 & & \\
\hline & Positive & $38(12.06 \%)$ & 2.195 & $0.283-17.029$ & 0.452 \\
\hline \multirow[t]{2}{*}{ LLINs } & No & $24(24.24 \%)$ & 1 & & \\
\hline & Yes & 15 (6.44\%) & 0.215 & $0107-0.431$ & $0.0001^{* * *}$ \\
\hline
\end{tabular}

\section{Discussion}

Blood donors (samples) were qualified based on results of mandatory serological tests for HIV, hepatitis B, hepatitis C and T. pallidum. These four infections were found in our recruited donors, with HIV and hepatitis B having higher prevalences. Because, these two infections cause chronic and life-threatening disorders diseases, we reaffirm the absolute necessity to screen all blood for these infections for an optimal safety of blood transfusion [1]. We suggest this screening to be done using rapid tests before blood collection in order to avoid manipulation and destruction of viral and/or bacterial infected blood samples. The fraction of recruited donors found infected by at least one of the four transfusiontransmissible infections diagnosed was close to this reported in a similar study conducted in Laquintinie hospital in Douala [12]. However, the prevalence of HIV infection (3.8\%) was above that reported in this previous study (1.8\%), and also above the Central African average in the Economic Community of Central African States (ECCAS) area (1.9\%) [11]. By contrast our HIV prevalence 
was under that reported in a similar study conducted in Yaoundé the capital city of Cameroon (4.4\%) [13], and under the national prevalence (4.30\%) [11].

On other hand, hepatitis prevalences obtained in this study where slightly higher than that observed in Laquintinie hospital in Douala [12], while the prevalence rate of syphilis infection is 7 -fold lower. Overall these differences in prevalences of viral and bacterial infections between cohorts of donors within the same city could more likely reflect intra-population variations rather than an increase/decrease of diseases transmission between the periods when the studies were conducted. Nevertheless, the fact that HIV and hepatitis infection prevalences are still high in the population underscore the necessity to continue hepatis and HIV/AIDS-related health education and prevention efforts in Cameroon, especially in young sexual active people. Two hemoparasite species namely L. loa the causative agent of loasis and P. falciparum the most dangerous and widespread malaria agent in sub-saharan Africa, have been found in qualified blood samples at the Douala General Hospital. However, L. loa has been identified only in two people and this low prevalence rate may be due to the fact that donors came from urban zones which are far from forest where vectors of filariasis are present. Thus the cases observed could be imported from forest areas or could be old cases, since L. loa can persist in human blood for several years [14].

The prevalence of assymptomatic malaria in qualified blood donors(samples) was $11.78 \%$ and was very close to that reported in student blood donors living in Douala in 2016 (10.17\%) [15]. Our prevalence was rather lower that observed among blood donors from other cities in Nigeria (25.9-40.9\%), a neighboring country [16 -18], but higher than that reported at the Komfo Anokye Teaching Hospital, Kumasi, in malaria-endemic Ghana (4.7\%) [19]. These differences could be due to variation in the patterns of malaria transmission in these cities, knowing that malaria transmission could vary depending of ecosystems and/or seasons. Additionally, since 2011 the Cameroonian government has proceeded to a massive distribution of LLINs, and this have certainly contributed to significantly reduce blood carriage of malaria parasite in population [11]. This argument is corroborated by the fact the nonuse of LLINs was associated with high risk of asymptomatic carriage of Plasmodium in this study. Similar to previous studies mentioned above, our results suggest a serious risk of transfusion-transmitted malaria in recipients in hospitals of Douala Cameroon. Since the children, pregnant women and probably immunocompromised people like HIV/AIDS patients constitute the bulk of the blood recipients and are also the groups the most at risk of malaria [15], the implications in terms of malaria-related morbidity and mortality are important. Premedication of donors has been shown efficient in reducing risk of transfusion-transmitted malaria [20].

This may be the best way to prevent post-transfusion malaria, but mainly in countries where a national blood transfusion service has been successfully set up or when free blood donation is well organized. This scheme contrast with the situation in Cameroon and several other sub-Saharan countries where transfused blood mostly come from family donors as exemplified in this study $[11,17,21]$. The fear of knowing their HIV or hepatitis B serological status, indolence, religion, some misconceptions like blood donor has risk for contracting infection like HIV or Hepatitis (B \& C) are among factors that limit voluntary donation of blood $[22,23]$. Alternative solution may consist of medication of blood recipients $24 \mathrm{~h}$ or immediately after blood transfusion and this has been shown to protect from induced malaria in tropical areas [20]. This solution better fits with the Cameroonian context where broad part of donors are recruited in emergency situations and cannot therefore be pre-treated, since the elimination of parasites from the blood could requires up to 48 hours [24].

In the other hand, our study population mostly consisted of single young males who attended secondary and university. This observation reinforced the view that young educated people are more sensitized about the importance of blood donation. Nevertheless, among them, males had significantly higher tendency toward donating blood compared to females [25,26]. The fact that females are more concerned by several exclusion criteria (pregnancy, breastfeeding, menstruations) may explain their poor participation to blood donation. Besides, religious factors coupled with the fear to know their serological status, especially vis-à-vis of HIV could have negative motivating effect on blood donation in women $[27,28]$.

\section{Conclusion}

The present study highlights the effective circulation of HIV, Hepatitis (B and C) and Syphilis infections in population of Douala and reaffirms the absolute necessity to systematically screen blood for these infections prior transfusion. Besides, the relative high prevalence rate of $P$. falciparum in blood donors provides evidence that transmission of this hemoparasite represents a real transfusion risk for blood receivers who are generally in bad health conditions. We advocate the necessity to establish a systematic Plasmodium screening, using malaria rapid diagnostic tests (RDT), in order to determine post-blood transfusion measures that have to be taken.

\section{Acknowledgement}

We are grateful to all participants and the medical staff of the General Hospital of Douala for their participation in this study.

\section{References}

1. (2011) WHO: Global database on blood safety: report?

2. (2016) WHO: Global status report on blood safety and availability.

3. Ogbu 0, Uneke C (2008) Hepatitis B Virus and Blood Transfusion Safety In Sub-Saharan Africa. Int J Infect Dis 7(2): 1-7.

4. Erhabor 0, Adias TC (2011) The challenges of meeting the blood transfusion requirements in Sub-Saharan Africa: the need for the development of alternatives to allogenic blood. J Blood Med 2: 7-21.

5. Ogbolu DO, Alli OT, Odeleye I, Oluremi AS (2016) High Seroprevalence of Asymptomatic Viral Haemoparasites Among Prospective Blood Donors in Nigeria. Asian Pac J Trop Med 9 (7): 658-661. 
6. Tessema B, Yismaw G, Kassu A, Amsalu A, Mulu A, et al. (2010) Seroprevalence of HIV, HBV, HCV and syphilis infections among blood donors at Gondar University Teaching Hospital, Northwest Ethiopia: declining trends over a period of five years. BMC Infect Dis 10: 1-7.

7. (2009) WHO: Screening donated blood for transfusion-transmissible infections.

8. Dodd RY (1998) Transmission of parasites by blood transfusion. Vox Sang 74 (2): 161-163.

9. Owusu-Ofori AK, Parry C, Bates I (2010) Transfusion-transmitted malaria in countries where malaria is endemic: a review of the literature from sub-Saharan Africa. Clin Infect Dis 51(10): 1192-1198.

10. Faruk JA (2016) Blood transfusion malaria: A literature review. Ann Nigerian Med 10(2): 49-57.

11. (2016) Ministry of Health of Cameroon: Health analytical Profile Cameroon 2016

12. Eboumbou Moukoko CE, Ngo Sack F, Essangui Same EG, Mbangue M Lehman LG, et al. (2014) HIV, HBV, HCV and T. pallidum infections among blood donors and Transfusion-related complications among recipients at the Laquintinie hospital in Douala, Cameroon.BMC Hematol 14(1): 5.

13. Fouelifack Ymele F, Keugoung B, Fouedjio JH, Kouam N, Mendibi S, et al (2012) High Rates of Hepatitis B and C and HIV Infections among Blood Donors in Cameroon: A Proposed Blood Screening Algorithm for Blood Donors in Resource-Limited Settings. J Blood Transfus p. 1-7.

14. Antinori S, Schifanella L, Million M, Galimberti L, Ferraris L, et al. (2012) Imported Loa loa filariasis: three cases and a review of cases reported in non-endemic countries in the past 25 years. Int J Infect Dis 16(9): e649-e662.

15. Koanga Mogtomo ML, Kojom Foko LP, Assokom Okoubalimba EV, Embolo Enyegue E, Ngono Ngane AR, et al. (2016) High Risk of TransfusionTransmitted Malaria (TTM) from Student Blood Donors Living in the Town of Douala, Cameroon. J Clin Infect Dis Pract 1(108): 1-2.

16. Uneke CJ, Ogbu O, Nwojiji V (2006) Potential risk of induced malaria by blood transfusion in South-eastern Nigeria. McGill J Med 9(1): 8-13.

17. Olawumi HO, Fadeyi A, Babatunde SK, Akanbi AA 2nd, Babatunde AS (2015) Malaria Parasitaemia among Blood Donors in Ilorin, Nigeria. Afr J Infect Dis 9(1): 10-13.

\section{ISSN: 2574-1241}

DOI: 10.26717/BJSTR.2019.18.003227

Cyrille NDO. Biomed J Sci \& Tech Res

This work is licensed under Creative Commons Attribution 4.0 License

Submission Link: https://biomedres.us/submit-manuscript.php
18. Oladeinde BH, Omoregie R, Osakue EO, Onaiwu TO (2014) Asymptomatic Malaria among Blood Donors in Benin City Nigeria. Iran J Parasitol 9(3): 415-422.

19. Owusu-Ofori AK, Betson M, Parry CM, Stothard JR, Bates I, et al. (2013) Transfusion-transmitted malaria in Ghana. Clin Infect Dis 56(12): 17351741.

20.BRUCE-CHWATT LJ (1974) Transfusion malaria. Bull World Health Organ 50(3-4): 337-346.

21. Messih IY, Ismail MA, Saad AA, Azer MR (2012) The Degree of Safety of Family Replacement Donors Versus Voluntary Non-Remunerated Donors in an Egyptian Population: A Comparative Study. Blood Transfus 12(2): 159-165

22. Baig M, Habib H, Haji AH, Alsharief FT, Noor AM, et al. (2013) Knowledge, Misconceptions and Motivations Towards Blood Donation Among University Students in KSA. Pak J Med Sci 29(6): 1295-1299.

23. Shah VB, Patil P, Sawant D, Deokar M (2011) A Study of Public Perception towards Blood Donation. Bombay Hos J 53 (1).

24. Maiga AW, Fofana B, Sagara I, Dembele D, Dara A, et al. (2012) No evidence of delayed parasite clearance after oral artesunate treatment of uncomplicated falciparum malaria in Mali. Am J Trop Med Hyg 87(1): $23-28$

25. Maotela Kabinda J, Ahuka Miyanga S, Ramazani SY, Dramaix MW (2014) Assessment of Knowledge, Attitude and Practice of the General Population of Bukavu in the Democratic Republic of Congo on Blood Donation and Blood Transfusion. Health 6(18): 2525-2534.

26. Mauka WI, Mahande MJ, Msuya SE, Philemon RN (2015) Factors Associated with Repeat Blood Donation at the Northern Zone Blood Transfusion Centre in Tanzania. J Blood Trans p. 6.

27. Pule PI, Rachaba B, Magafu MGDM, Habte D (2014) Factors Associated with Intention to Donate Blood: Sociodemographic and Past Experience Variables. J Blood Trans.

28. Okpara RA (1989) Attitudes of Nigerians towards blood donation and blood transfusion. Trop Geogr Med 41(1): 89-93.

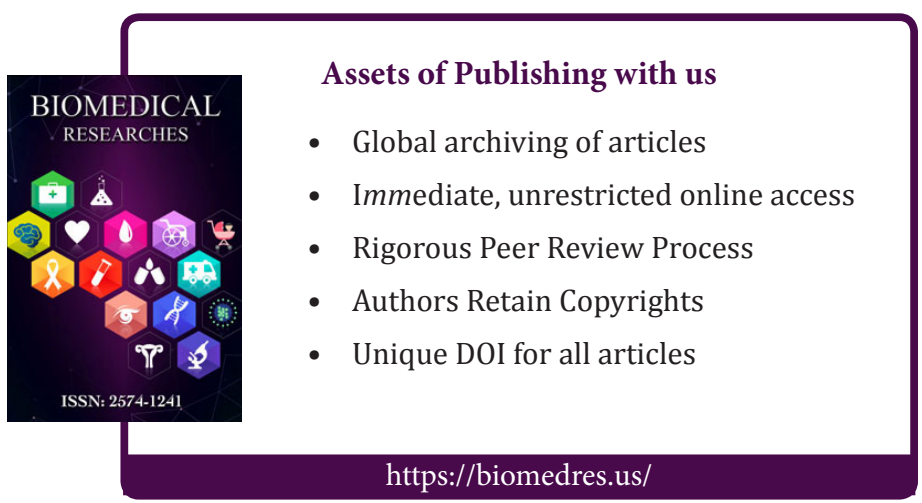

